\title{
PARADIGMA MISI DOKTER KRISTEN DI INDONESIA DALAM TERANG INJIL LUKAS
}

\author{
Simon Alexander Tarigan \\ sttjaffraymakassar@yahoo.co.id \\ Peter Anggu \\ sttjaffraymakassar@yahoo.co.id
}

\begin{abstract}
ABSTRAK
Sesuai dengan pokok masalah yang ada, maka yang menjadi tujuan dalam penulisan karya ilmiah ini adalah: untuk mengetahui pelaksanaan misi oleh dokter Kristen di Indonesia dan sejauh mana misi itu dijalankan dilihat dalam terang Injil Lukas.

Adapun metode penulisan yang digunakan dalam penulisan karya ilmiah ini untuk mendapatkan data yang diperlukan adalah: Metode penelitian yang digunakan adalah "Penelitian Survei." Populasinya adalah dokter Kristen yang ada di kota besar di Indonesia di mana sampelnya diambil secara acak. Pengambilan data dilakukan dengan kuesioner dan wawancara.

Adapun kesimpulan dari hasil penelitian dan pembahasan karya ilmiah ini adalah: Pertama, jika misi dilihat dari aspek kasih, dapat dikatakan dokter Kristen dalam penelitian ini belum terlalu materistis dan telah mempraktikkan kasih itu, khususnya dengan keberpihakan mereka kepada orang-orang miskin. Kedua, pengakuan iman yang baik tidak diimplementasikan dalam kehidupan sehari-hari seperti membaca Alkitab dan berdoa secara teratur. Ketiga, meskipun mayoritas responden sadar bahwa pekerjaan mereka sebagai dokter adalah panggilan Tuhan untuk melayani, namun kesibukan, padatnya jadual telah membuat panggilan itu menjadi kabur. Keempat, bahaya legalisme mulai tampak melihat banyaknya jumlah mereka yang bersaksi secara verbal, namun tanpa spiritualitas, mempraktikkan kasih tanpa nilai kemanusiaan yang utuh, pengakuan iman dengan bukti yang samar-samar. Kelima, sekalipun dari aspek kasih, dokter-dokter Kristen dalam penelitian ini kelihatannya sudah melaksanakan misinya, namun secara keseluruhan, setelah dianalisis melalui komparasi, interpretasi dan deskripsi, secara deduktif dapat diambil kesimpulan akhir bahwa mayoritas dokter Kristen dalam penelitian ini dan dokter Kristen di Indonesia mempunyai keinginan untuk melaksanakan misinya, namun masih jauh dari paradigma misi Injil Lukas.
\end{abstract}

Kata kunci: Paradigma misi, dokter Kristen Indonesia, Terang, Injil Lukas 


\section{PENDAHULUAN}

\section{Latar Belakang Masalah}

Misi Kristen adalah sebuah tugas yang dari sisi ilmu pengetahuan didekati dengan ilmu yang dikenal sebagai "Misiologi." Bosch mengatakan, bahwa sejarah dan teologi kekristenan yang mula-mula adalah "sejarah misi" dan " teologi misi."

Lukas adalah salah satu dari tiga penulis Injil Sinoptik yang memuat tentang sejarah misi Kristen di atas. Lukas menulis Injilnya dengan maksud agar orang-orang Kristen pada waktu itu memahami bahwa Allah mengutus anak-Nya Yesus Kristus untuk menyelamatkan seluruh manusia tanpa memandang ras, agama, status sosial atau alasan diskriminatif lainnya.

Mengenai Injil Lukas, Drane berkata, "Suatu ciri yang menonjol dari Injil Lukas adalah Kabar Baik tentang Yesus berlaku bagi semua orang." 2 Selanjutnya Duyverman menjelaskan, tujuan Lukas dalam menulis Injilnya adalah, "Untuk memberi kesaksian yang berdasarkan kepercayaan tentang pekerjaan Yesus, bahwa di dalam Dia keselamatan itu juga disuguhkan sepenuhnya kepada orang bukan Yahudi, orang yang hina dina dan orang-orang berdosa." Jadi, dapat dikatakan, misi Lukas dalam Injilnya bersifat inklusif.

Kita dapat melihat inklusivitas misi Lukas itu dalam cerita-cerita yang diangkatnya dalam Injilnya. Demikian juga kita dapat melihatnya dalam tulisan keduanya, yaitu Kisah Para Rasul 15, yang bukan secara kebetulan dilaporkan oleh Lukas, yaitu tentang pertentangan yang terjadi di Yerusalem akibat misinya kepada orang-orang non Yahudi.

Pada zaman ini, seluruh orang Kristen idealnya melaksanakan praktek misi Injil Lukas dalam kehidupan mereka setiap hari dalam arti seluas-luasnya. Hanya dengan demikian maksud pelayanan Yesus yang dicatat oleh Lukas dapat disampaikan kepada orang-orang lain, secara khusus, mereka yang terbelit dengan kemiskinan, ketidak mampuan dan sejenisnya.

Dalam konteks Indonesia, yang terdiri atas bermacam-macam suku, agama, ras dan masih banyaknya masyarakat yang miskin, inklusivitas Injil Lukas seperti yang telah disebut di atas semakin menjadi penting.

Dokter Kristen di Indonesia adalah bagian dari komunitas orang Kristen yang terhisab ke dalam misi di atas. Dokter Kristen di Indonesia

\footnotetext{
${ }^{1}$ David J. Bosch, Transformasi Misi Kristen (Jakarta: BPK Gunung Mulia, 2004), 21.

${ }^{2}$ John Drane, Memahami Perjanjian Baru (Jakarta: BPK Gunung Mulia, 1996), 214.

${ }^{3}$ M.E. Duyverman, Pembimbing ke Dalam Perjanjian Baru (Jakarta: BPK Gunung Mulia, 1998), 58.
} 
merupakan bagian dari Asosiasi Internasional Dokter dan Dokter Gigi Kristen (ICMDA). Asosiasi ini terdiri atas asosiasi-asosiasi dokter dan dokter gigi nasional yang otonom dan berusaha memelihara kehidupan rohani para profesional Kristen yang bekerja di bidang kedokteran dan kedokteran gigi serta mendorong mereka untuk menyaksikan iman mereka dalam profesinya dan menerapkan azas Kristen dalam praktik profesi dan etikanya. ${ }^{4}$

Beberapa persoalan yang timbul dalam pelayanan dokter Kristen sehari-hari dalam misinya adalah pelayanan yang dirasakan semakin menjauh dari orang miskin, yang terbelakang serta semakin jauh dari nilai-nilai kristiani. Pasien hanya dianggap sebagai objek yang martabat dan haknya diabaikan. Pasien juga dipaksa berinteraksi dengan ilmu dan teknologi kesehatan ketimbang dengan dokter sebagai sesama manusia. Diagnosis bergeser dari ruang praktek menuju lembaga yang lebih besar yang semakin mahal dan tidak terjangkau oleh masyarakat khususnya mereka yang tidak mampu.

Dokter Kristen, sama seperti dokter lainnya, pada mulanya menginginkan suatu pelayanan yang ideal dan manusiawi, namun realitasnya adalah mereka kemudian terjebak ke dalam pelayanan yang tidak manusiawi. Kasus-kasus malpraktik yang banyak kita dengar, diagnosis yang berlebihan, pemakaian obat yang tidak rasional dan pemakaian alat-alat canggih yang tidak terjangkau oleh pasien adalah beberapa buktinya. Problem ini semakin diperparah dengan kemajuan dan penemuan-penemuan teknologi baru dalam bidang kesehatan, seperti pengembangan alat-alat diagnostik yang canggih, pengembangan biomedis dan rekayasa genetika yang semuanya memerlukan biaya yang mahal dan semakin tidak terjangkau oleh pasien.

Hugh F. Lena dan kawan-kawan mengkritisi kemajuan di atas dalam bukunya Issues in Society mengatakan, "Medical care has come to epitomize many of critical dilemmas that confront contemporary societies especially those pertaining to production and use of complex technology and use scientific and professional knowledge."

Hal lain adalah materialisme. Dalam diskusi panel terbatas Kompas bersama Ikatan Alumni Universitas Indonesia-Fakultas Kedokteran Universitas Indonesia 1987 di Jakarta, Ketua Konsil Kedokteran Indonesia, Prof. Menaldi Rasmin mengatakan, "Budaya materialistik, biaya pendidikan dokter yang mahal, rendahnya insentif bagi para dokter dan buruknya sistem layanan kesehatan telah

${ }^{4}$ Tim ICMDA, Sumber Hidup Praktisi Medis (Jakarta: Yayasan Bina kasih/OMF, 2002), 398.

${ }^{5}$ Hugh F. Lena et All, Issues in Society (New York-Singapore: Mac Graw Hill Inc, 1992), 402. 
mengancam kehormatan profesi dokter." ${ }^{6}$ Budaya materialistik dapat membuat dokter kehilangan belas kasihan terhadap pasien-pasiennya.

Hans Kung dalam bukunya On Being Christian mengatakan, " $\mathrm{Hal}$ terpenting dalam kehidupan modern adalah keuntungan perseorangan. Kita tidak lagi bertanya tentang "siapa dia" seperti kita bertanya "apa dia." Dalam hal ini maksud kita adalah pekerjaannya, keberhasilannya, posisinya dan status sosialnya."7

Hans Kung rupanya melihat suatu perubahan dalam masyarakat modern dalam memandang manusia dimana sebagai akibat materialisme, manusia hanya dipandang sebagai objek dari kegiatan yang hanya mendatangkan keuntungan pada dirinya.

Di samping itu, hubungan dokter-pasien yang tidak seimbang juga telah menjadi lahan subur bagi praktek yang tidak sesuai dengan nilainilai kristiani. Menurut Szas dan Holander seperti yang dikutip oleh Benyamin Lumenta dalam bukunya "Pasien, Citra dan Perilaku", "Hubungan dokter-pasien yang paling dikenal adalah pola hubungan pasif-aktif." 8 Menurut pola hubungan dokter-pasien di atas, pasien tidak mempunyai otonomi atas dirinya sendiri dan hanya bersikap pasif terhadap segala sesuatu yang dilakukan dokter kepadanya.

Injil Lukas adalah sebuah dokumen misi yang ditulis oleh seorang dokter. Sementara dokter Kristen di Indonesia dalam misinya sedang ditantang oleh berbagai hal yang telah disebut di atas. Melalui eksplorasi beberapa pokok tentang misi dari Injil Lukas penulis ingin melihat sejauh mana dokter Kristen di Indonesia melakukan misinya dalam karya ilmiah: "Paradigma Misi Dokter Kristen di Indonesia Dalam Terang Injil Lukas.”

\section{Pokok Masalah}

Dengan melihat latar belakang masalah di atas, masalah pokok yang ingin dibahas dalam karya ilmiah ini adalah:

Pertama, di zaman modern ini, di tengah-tengah kehidupan yang semakin materialistis, hubungan dokter-pasien yang tidak seimbang dengan kemajuan pengetahuan dan teknologi kedokteran yang ada saat ini, penulis ingin mengetahui apakah dokter Kristen mengemban misi Kristen dalam menjalankan profesinya ?

Kedua, sejauh mana para dokter Kristen telah melaksanakan misi itu dilihat dalam terang Injil Lukas.

\footnotetext{
6“Semangat Pengabdian Dokter Luntur," Kompas, 4 Mei 2012, 13.

${ }^{7}$ Hans Kung, On Being Christian (New York: Doubleday \& Company Inc, 1974), 582.

${ }^{8}$ Benyamin, Lumenta, Pasien. Citra, Peran dan Perilaku (Yogyakarta: Kanisius, 1989), 73
} 


\section{Tujuan Penelitian}

Untuk mengetahui pelaksanaan misi oleh dokter Kristen di Indonesia dan sejauh mana misi itu dijalankan dilihat dalam terang Injil Lukas.

\section{Manfaat Penelitian}

Pertama, bermanfaat bagi semua dokter Kristen di Indonesia untuk introspeksi diri dalam pelayanannya setiap hari.

Kedua, bermanfaat bagi gereja untuk membina dokter-dokter Kristen yang menjadi anggotanya.

Ketiga, karena penulis kebetulan adalah dosen paruh waktu di Sekolah Tinggi Theologia Jaffray Makassar, maka tulisan ini bermanfaat bagi Sekolah Tinggi Theologia Jaffray Makassar sebagai sebuah penelitian ilmiah.

Keempat, sebagai syarat bagi penulis untuk menyelesaikan program magister teologi di Sekolah Tinggi Theologia Jaffray Makassar.

\section{Metode Penelitian}

Metode penelitian yang digunakan adalah "Penelitian Survei." Populasinya adalah dokter Kristen yang ada di kota besar di Indonesia di mana sampelnya diambil secara acak. Pengambilan data dilakukan dengan kuesioner dan wawancara,

\section{Batasan Penulisan}

Misi mengandung pengertian yang sangat luas, itu sebabnya tidaklah mungkin menulis semua tentang misi dalam karya ilmiah ini. Tulisan dalam karya ilmiah ini dibatasi pada misi dalam Injil Lukas sebagai instrumen untuk melihat paradigma misi dokter Kristen di Indonesia.

\section{METODOLOGI PENELITIAN}

\section{Gambaran Umum Objek Penelitian}

Objek material penelitian ini adalah paradigma misi dokter Kristen di seluruh Indonesia yang masuk dalam penelitian ini sedang objek formalnya adalah Injil Lukas. Pengambilan sampel dilakukan pada kota-kota besar seperti Medan, Jakarta, Bandung, Makassar, Manado, Biak dan Kupang. Alasan penulis untuk mengambil sampel dari daerahdaerah tersebut adalah,

Pertama, dokter banyak tinggal di perkotaan 
Kedua, kota-kota itu adalah kota-kota besar di Indonesia yang dapat dianggap sebagai representasi Indonesia.

Ketiga, penulis adalah seorang dokter sehingga lebih mudah berhubungan dengan para dokter yang ada di kota besar tersebut.

Keempat, untuk penelitian jenis ini, penulis yakin para dokter Kristen belum pernah jadi objek penelitian.

\section{Gambaran Singkat Dokter Kristen di Indonesia}

Dokter Kristen di Indonesia adalah bagian dari Asosiasi Internasional Dokter dan Dokter Gigi Kristen atau The International Christian Medical and Dental Association (ICMDA). Asosiasi ini terdiri dari asosiasi-asosiasi dokter dan dokter gigi nasional yang otonom dan berusaha memelihara kehidupan rohani para profesional Kristen yang bekerja di bidang kedokteran dan kedokteran gigi serta mendorong mereka untuk menyaksikan iman mereka dalam profesinya serta menerapkan azas Kristen dalam praktik profesi dan etikanya. ${ }^{9}$

Asosiasi ini menyediakan sarana untuk bertukar pikiran, informasi dan pengalaman secara teratur dalam ilmu kedokteran dan kedokteran gigi, terutama yang berkaitan dengan iman dan etika Kristen. Asosiasi juga berusaha memelihara kehidupan rohani para profesional Kristen yang bekerja di bidang kedokteran dan kedokteran gigi, mendorong mereka untuk menyaksikan imannya dan juga mendukung pekerjaan badan misi medis Kristen kedokteran dan kedokteran gigi.

Secara nasional, dokter Kristen di Indonesia belum mempunyai persekutuan yang resmi. Namun demikian, di beberapa daerah seperti Makassar dan beberapa daerah lain, atas inisiatif beberapa orang dokter sudah ada persekutuan yang bersifat antar-denominasi yang menghimpunkan dokter Kristen di kota itu dalam satu wadah yang secara rutin mengadakan pertemuan. Pertemuan mereka diisi dengan kegiatan ibadah serta menjadi sarana untuk bertukar pikiran, informasi dan pengalaman dari masing-masing dokter Kristen.

Menurut dr. Bambang, Direktur Umum RS. Imanuel Bandung, dalam wawancara oleh penulis tanggal 27 Desember 2011 di RS. Imanuel Bandung. Dr. Bambang mengatakan, "Setahu saya, di Bandung saat ini belum ada wadah yang menghimpun seluruh dokter Kristen, hal itu mungkin disebabkan oleh kesibukan para dokter dalam melayani pasienpasien mereka."

Sementara itu dalam percakapan dengan dr. Ranto Bonar Sinaga Sp. Obstetri \& Gynecology di Medan, dr. Ranto Bonar Sinaga

\footnotetext{
${ }^{9}$ Sumber Hidup Praktisi Medis, Terj. Tim Yayasan Komunikasi Bina Kasih (Jakarta: Yayasan Bina kasih/OMF, 2002), 398.

${ }^{10}$ Bambang, Wawancara oleh penulis, Bandung, Jawa Barat. 27 Desember 2011.
} 
mengatakan, "Kurangnya keinginan akan hal-hal rohani menyebabkan susah sekali menghimpunkan dokter Kristen di Medan."ll Hal yang sama dikatakan oleh dr. Ronny Tumbel Sp. THT di Manado. ${ }^{22}$ Persekutuan di Manado hanya terbatas di satu rumah sakit. Hal yang sama terjadi di Jakarta, Bandung dan tempat-tempat lainnya.

Majalah Nature pada bulan Februari 1997 memuat sebuah artikel yang berjudul Viable Offspring Derived From Fetal and Adult Mamalian Cells. ${ }^{13}$ Kemajuan ilmu pengetahuan dan teknologi yang ditandai dengan keberhasilan melahirkan domba Dolly tanpa melalui perkawinan normal atau apa yang dikenal sebagai "kloning" telah membuka peluang bagi manusia untuk mengklon manusia.

Sejak saat itu, isu tentang kloning telah menjadi perdebatan di kalangan para dokter dan ahli genetika. Kita tidak dapat membayangkan apa yang terjadi dengan manusia di masa depan jika hal itu terjadi. Dapat diperkirakan, jika hal itu terjadi maka akan terjadi kehancuran manusia sebagai makhluk ciptaan Allah

Teknologi-teknologi lain dalam bidang kedokteran akan semakin berkembang pada masa depan, itu sebabnya, para dokter Kristen perlu terus mencari kehendak Tuhan dalam mengembangkan dan menjalankan profesinya di tengah-tengah masyarakat. Hal itu paling baik dilakukan jika para dokter mempunyai wadah bersama di mana mereka dapat berkumpul bersama untuk membicarakan hal itu dan menyelidikinya dalam terang firman Tuhan.

\section{Jenis Penelitian}

Penelitian ini adalah penelitian lapangan, memakai kuesioner dan memakai Injil Lukas sebagai paradigmanya. Namun demikian, hasil wawancara dan jawaban pada beberapa pertanyaan di dalam kuesioner.

\section{Rencana Penelitian}

Penelitian yang digunakan adalah "Penelitian Survei." Populasinya adalah dokter Kristen yang ada di Kota besar di Indonesia seperti Medan, Jakarta, Bandung, Makassar, Manado, Biak dan Kupang.

Sampelnya diambil secara acak dan pengambilan data dilakukan dengan kuesioner. Untuk melengkapi data yang sudah didapat, penulis melakukan wawancara, baik langsung maupun melalui telephone. Hasil penelitian akan dilengkapi dengan penelitian terhadap beberapa kepustakaan.

\footnotetext{
${ }^{11}$ Ranto Bonar Sinaga, Wawancara oleh penulis, 18 Mei 2012.

${ }^{12}$ Ronny Tumbel, Percakapan telepon dengan penulis, 20 Februari 2012.

${ }^{13}$ I.Wilmut et all, "Viable Offspring Derived From Fetal and Adult Mamalian Cells" Nature, Feb, 1997, 385.
} 


\section{ANALISIS HASIL DAN PEMBAHASAN}

\section{Analisis Hasil Penelitian}

Jumlah dan Karakteristik Responden

Tabel 1. Jumlah Kuesioner dan Responden

\begin{tabular}{|l|c|c|}
\hline Jumlah kuesioner yang dibagikan & 140 & $100 \%$ \\
\hline $\begin{array}{l}\text { Jumlah kuesioner yang kembali (jumlah } \\
\text { responden) }\end{array}$ & 115 & $82,14 \%$ \\
\hline
\end{tabular}

Seratus empat puluh kuesioner telah dibagikan di tujuh kota yang menjadi objek penelitian ini, atau 20 kuesioner di tiap kota dengan pengembalian sebanyak 115 kuesioner $(82,14 \%)$ yang sekaligus menjadi responden dalam penelitian ini, (Tabel 1).

Dari 115 responden, ada beberapa responden yang tidak menjawab beberapa pertanyaan yang ada dalam kuesioner atau ada juga yang menjawab ganda. Ada kemungkinan hal itu disebabkan oleh keraguan responden dalam menjawab pertanyaan-pertanyaan tersebut.

Hal itu menimbulkan kerumitan tersendiri dalam penghitungan dan analisis data. Berdasarkan konsultasi penulis dengan Pdt. Dr. Ivan Weisman, penghitungan data tetap dapat dilakukan dengan menjadikan "115 responden yang menyerahkan kuesioner" sebagai basis penghitungan data. ${ }^{14}$ Hal yang sama dikatakan oleh Benyamin Pasulean, Ph.D, Untuk responden seperti itu jawaban tidak dapat dinilai namun tetap sebagai responden.

Tabel 2. Sebaran Responden Berdasarkan Keahlian

\begin{tabular}{|l|l|l|}
\hline Dokter umum & 39 & $33.91 \%$ \\
\hline Dokter ahli tanpa pisau & 31 & $26,95 \%$ \\
\hline Dokter ahli dengan pisau & 45 & $39,13 \%$ \\
\hline Jumlah & 115 & $100 \%$ \\
\hline
\end{tabular}

\footnotetext{
${ }^{14}$ Ivan Weisman, konsultasi dengan penulis, Makassar, Sulawesi-Selatan, 10 Mei 2012.

${ }^{15}$ Benyamin Pasulean, konsultasi dengan penulis, Makassar, Sulawesi-Selatan, 16
} Mei 2012 
Sebaran responden berdasarkan keahlian adalah 39 (33,9l\%) dokter umum, 31 (26,95\%) orang dokter ahli tanpa operasi dan 45 $(39,13 \%)$ orang dokter ahli dengan operasi, (Tabel 2).

\section{Misi Dokter Kristen Dalam Hubungannya Dengan Kasih}

Meskipun sangat sukar untuk mengukur kasih Kristen, namun dalam karya ilmiah ini kasih dokter Kristen dicoba untuk diukur dengan melihat sensitivitas mereka terhadap penderitaan pasien yang sedang mereka hadapi. Hal itu diukur dari tarif, pemberian obat dan perasaan mereka melihat penderitaan pasien. Lebih dalam lagi, hal itu dibandingkan dengan apakah mereka juga berdoa untuk pasien mereka.

Dalam penelitian pendahuluan penelitian ini, pada pengalaman empiris beberapa dokter serta observasi penulis pada beberapa pasien, sensitivitas dokter dengan pasiennya dapat diukur dengan cara-cara seperti yang sudah dikatakan di atas. ${ }^{16}$ Kasih dokter Kristen memang sukar untuk diukur, namun kasih itu dapat dirasakan, diartikulasikan dan dilihat dalam pelayanan sehari-hari.

Ada 20 responden (17,39\%) yang mempunyai pasien dari golongan menengah-atas, 82 (71,30\%) golongan menengah-bawah, 6 (5,2\%) golongan bawah, 4 responden $(3,4 \%)$ dari golongan tidak mampu dan ada 3 responden (2,60\%) yang menjawab ganda sehingga jawaban tidak dapat dinilai, namun tetap dimasukkan sebagai responden.

Jika status ekonomi pasien disederhanakan, di mana golongan menengah-bawah, golongan bawah dan golongan tidak mampu dikelompokkan menjadi satu golongan menjadi golongan menengahtidak mampu, maka ada 92 responden (80\%) yang mempunyai pasien dari golongan menengah-tidak mampu, 20 (17,39\%) mempunyai pasien dari golongan menengah-atas dan ada 3 responden $(2,60 \%)$ yang menjawab ganda.

Responden menarik tarif kepada pasien dengan cara yang bervariasi, mulai dari tarif yang seragam sampai memberi gratis bagi pasien yang tidak mampu.

Jika status ekonomi pasien dihubungkan dengan tarif yang mereka tarik, maka mayoritas responden yang mempunyai pasien dari golongan menengah-tidak mampu masih menerapkan tarif yang fleksibel terhadap pasien mereka. Ketidak sesuaian jumlah pada kolom golongan menengah-tidak mampu disebabkan ada 3 responden yang menjawab ganda pada pertanyaan "golongan ekonomi pasien" sehingga jawabannya tidak dapat dinilai, sementara, semua responden menjawab pada pertanyaan "tarif" dapat dinilai.

\footnotetext{
${ }^{16}$ Pembicaran dengan beberapa dokter dan observasi pada beberapa pasien sebagai penelitian pendahuluan selama November-Desember, 2012 di Makassar.
} 
Bentuk fleksibilitas tarif itu mulai dari menyerahkan pembayaran kepada kemampuan pasien sampai kepada memberi gratis bagi mereka yang tidak mampu. Jika responden dipersempit kepada dokter yang mempunyai pasien dari golongan menengah-atas - sekaligus menguji data di atas - maka 13 dari 20 responden (65\%) yang mempunyai pasien dari golongan menengah-atas juga memberikan tarif yang fleksibel kepada pasien mereka.

Jika keduanya (golongan menengah-atas dan menengah-tidak mampu) digabungkan, maka ada 107 responden (93,04\%) yang tarif pemeriksaannya fleksibel. Fleksibilitas itu mulai dari menyerahkannya kepada kemampuan pasien sampai memberi gratis kepada mereka yang tidak mampu.

Hal yang sama juga ditunjukkan oleh dokter yang memegang pisau (dokter bedah). Dari 45 dokter bedah, 33 (73,33\%) menerapkan tarif yang fleksibel. Hanya 12 dari 45 dokter bedah (26,66\%) yang menerapkan tarif yang seragam. Hal di atas menunjukkan bahwa dari aspek tarif responden belum terlalu materialistis dan masih sensitif terhadap keadaan ekonomi pasien.

Data penulisan resep juga memperkuat hasil di atas. Dari seluruh responden, 112 (97,39\%) menuliskan resep berdasarkan kesanggupan, generik atau rasionalitas. Ada 1 responden $(0,86 \%)$ yang menuliskan resep berdasarkan komisi dari perusahaan obat dan 2 responden (1,73\%) tidak menjawab.

Ada 26 responden $(22,60 \%)$ yang selamanya ikut merasakan penderitaan pasien mereka, 37 (32,17\%) ikut merasakannya jika penyakitnya berat dan 47 responden $(40,86 \%)$ mendoakan pasien mereka secara pribadi. Ada 4 responden yang tidak menjawab.

\section{Misi, Nilai Manusia dan Etika Kedokteran}

Pekerjaan dokter adalah menyangkut kesehatan dan hidup manusia. Oleh karena itu, dalam penerapannya sangat ditentukan seberapa besar nilai manusia itu mereka nilai. Ada dua tindakan dokter Kristen yang ingin dilihat dalam bagian ini, yakni abortus dan eutanasia.

Abortus dan eutanasia telah menjadi isu internasional dan nasional yang pelik karena menyangkut berbagai aspek seperti aspek juridis, teologis, etis, moral dan sosial. Masalah di atas menjadi lebih kompleks karena kedua masalah itu juga menyangkut aspek personal. Masalah abortus menjadi personal karena menyangkut seksualitas, reproduksi dan hak wanita atas kandungannya, sedangkan masalah eutanasia karena menyangkut hak seseorang untuk menentukan hidupnya.

Di masa depan dengan budaya yang semakin permisif terhadap persoalan etis dan moral, maka isu ini akan menjadi semakin penting untuk diperhatikan. Permintaan untuk melakukan abortus dengan 
berbagai alasan diperkirakan akan semakin banyak. Akibatnya, tidak tertutup kemungkinan akan terjadinya komersialisasi tindakan abortus akibat permintaan yang tinggi.

\section{Abortus}

Abortus adalah tindakan penghentian kehamilan sebelum janin berumur kurang dari dua puluh delapan minggu atau berat janin kurang dari 1000 gram. ${ }^{17}$ Abortus provokatus non-medisinalis adalah tindakan penghentian kehamilan seperti di atas, namun tanpa indikasi medis yang tepat dan ilegal.

Dalam penelitian ini, 92 dari 115 responden (80\%) adalah pro-life. Mereka menjawab bahwa abortus provokatus non-medisinalis "tidak boleh dilaksanakan." 46 orang (40\%) mempertegasnya dengan mengatakan bahwa "hal itu melanggar sepuluh hukum Allah." Hanya 9 responden $(7,82 \%)$ yang pro-choice atau "menyetujui tindakan abortus provokatus non-medisinalis." Ada 14 responden (12,17\%) yang tidak menjawab.

Ironisnya, meskipun mayoritas, 92 responden (80\%) menjawab "mutlak tidak boleh dilaksanakan," namun ada 60 responden $(52,17 \%)$ yang mengetahui bahwa ada dokter Kristen yang melakukan abortus di mana 40 responden $(34,78 \%)$ pernah mendengarnya dan 20 responden $(17,39 \%)$ mengetahui dengan pasti. Jika ditambah mereka yang menjawab "tidak tahu" 47 (40,86\%) jumlahnya menjadi 107, (93,04\%). Ada 3 responden $(2,60 \%)$ yang tidak menjawab.

Dalam wawancara penulis dengan dr. Srimawati Sembiring di Medan pada Desember 201l, dr. Srimawati Sembiring mengatakan, "Saya tahu pasti, tanpa ingin menyebut nama, ada dokter Kristen yang melakukan hal itu hanya untuk uang beberapa juta rupiah. Hal itu bukan hanya dilakukan oleh satu orang dokter, tapi dilakukan oleh beberapa dokter Kristen." 18

\section{Eutanasia}

Menurut Kartono Muhammad, dalam kalangan dokter istilah eutanasia berarti, "Membantu seseorang untuk mati lebih cepat demi untuk membebaskannya dari penderitaan akibat penyakitnya." 19

\footnotetext{
${ }^{17}$ Sarwono Prawiroharjo, Ilmu Kebidanan (Jakarta: Yayasan Bina Pustaka, 1981), 743.

${ }^{18}$ Srimawati Sembiring, Wawacra Oleh Penulis, Medan, Sumatera Utara, 23 Desember 2011.

${ }^{19}$ Kartono Muhammad, Teknologi Kedokteran dan Tantangannya Terhadap Bio Etika (Jakarta: PT. Gramedia Pustaka Utama, 1992), 19.
} 
Dalam penelitian ini, ada 99 responden $(86,08 \%)$ yang menjawab, dokter Kristen "tidak boleh melakukan eutanasia" dimana 56 (48,69\%) menjawab bahwa hal itu "melanggar perintah Allah" dan 43 $(37,39 \%)$ menjawab hal itu "melanggar sumpah dokter." Ada 8 responden (6,95\%) mengatakan, "boleh," di mana ada 2 di antaranya (1,73\%) mengatakan, "boleh jika diminta oleh pasien." Ada 8 responden yang tidak menjawab.

Namun ketika menjawab pertanyaan, "adakah dokter Kristen yang melakukan eutanasia"? Ada 29 responden $(25,21 \%)$ menjawab "ada dokter Kristen yang melakukan hal itu" di mana 15 (13,04\%) "pernah mendengar", 14 (12,17\%) "tahu pasti" ada dokter Kristen yang melakukan hal itu dan 8 responden (6,95\%) tidak menjawab, (Tabel 13).

Jika kedua kelompok yang "pernah mendengar" dan yang "tahu pasti ada yang melakukan eutanasia" digabungkan dengan responden yang menjawab tidak tahu jumlahnya menjadi 104 (90,43\%). Hanya 9 $(7,82 \%)$ responden yang merasa pasti "tidak ada dokter Kristen yang melakukan hal itu".

\section{Etika Kedokteran}

Dalam pelayanannya sehari-hari seorang dokter Kristen haruslah berpegang pada etika dan sumpah dokter. Dapat dikatakan, etika dan sumpah dokter adalah kompas yang menuntun dokter dalam semua tindakan-tindakannya.

Dalam penelitian ini hanya 30 (26,08\%) yang mengatakan bahwa dokter-dokter Kristen masih memegang teguh kode etik dan sumpah dokter. Ada 10 responden (8,69\%) yang mengatakan "dokter Kristen kurang memegang kode etik dan sumpah dokter," dan 71 (61,73\%) mengatakan "sebagian memegang, sebagian tidak." Jika kedua kelompok digabungkan, ada 81 responden (70,43\%) menganggap bahwa dokter Kristen saat ini sudah kurang memegang teguh kode etik dan sumpah dokter. Hanya 4 responden $(3,47 \%)$ yang tidak menjawab. Ada 8 responden $(3,47 \%)$ yang tidak menjawab, (Tabel 14).

Hasil di atas didukung oleh data abortus dan eutanasia, di mana ada di antara dokter-dokter Kristen di Indonesia ini yang melakukan kedua tindakan tersebut di atas. 52,17\% melakukan aborsi dan 25,21\% melakukan eutanasia.

\section{Hubungan Dokter-Pasien Sebagai Hubungan Antar Manusia}

Hubungan antar-manusia adalah penting dalam misi. Yesus sangat menghargai otonomi manusia dalam hubungan antar-manusia.

Jika kualitas hubungan dokter-pasien ditinjau dari bentuk hubungan itu sendiri, maka 95 responden $(82,60 \%)$ dalam penelitian ini menginginkan bentuk hubungan yang setara dengan pasiennya di mana 
$75(65,21 \%)$ menginginkan kesetaraan dengan menyerahkan keputusan pada pasien dan $20(17,39 \%)$ tetap menginginkan pengambilan keputusan tetap ada pada dokter. Hanya 13 responden $(11,30 \%)$ dalam penelitian ini yang masih mempertahankan hubungan yang paternalistik dan 5 responden (4,34\%) tidak menjawab pertanyaan, (Tabel 15).

Jika praktik kesetaraan hubungan dokter-pasien di atas dilihat dari aspek peresepan obat, kesetaraan itu tampak di mana 112 (97,39\%) responden masih memberi obat dengan kriteria, rasionil, berdasarkan kepada kesanggupan pasien dan obat generik. Hanya ada 1 responden $(0,86 \%)$ yang memaksakan peresepan obat kepada pasien mereka.

\section{Paradigma Misi Serta Kualifikasi Rohani Dokter Kristen}

Bagian ini ingin menunjukkan tentang pentingnya suatu kualitas rohani atau spiritualitas bagi seorang yang ingin menjadi pelayan Tuhan. Bagi dokter Kristen spiritualitas penting untuk mendukung pelayanan yang rutin mereka lakukan. Tanpa spiritualitas yang baik, di tengah semua kesibukan yang ada, seorang dokter Kristen hanya menjalani tugasnya sebagai sesuatu yang rutin. Dia hanya melakukan sesuatu seperti dokter lain melakukannya

Ada $47,82 \%$ responden yang berdoa setiap hari namun hanya $32,17 \%$ yang berdoa serta membaca Alkitab setiap hari. Sisanya hanya berdoa jika ada masalah atau malah sama sekali tidak berdoa.

\section{Pengakuan Iman}

Sama halnya dengan kasih, spiritualitas juga adalah hal yang susah untuk diukur. Meskipun demikian, dalam penelitian ini spiritualitas dokter Kristen dicoba untuk diukur dengan mengajukan beberapa pertanyaan yang berkaitan dengan pengakuan iman mereka, pendapat mereka tentang sembuh serta area pelayanan dokter Kristen. Pengakuan iman meliputi pengakuan mereka terhadap Yesus Kristus, Roh Kudus dan gereja. Hal tersebut kemudian dibandingkan dengan implementasinya dalam kehidupan dan pelayanan mereka sehari-hari.

Seluruh responden mengakui, "Yesus Kristus sebagai Tuhan, Juruselamat dunia dan Penebus dosa manusia." Ada 109 responden (94,78\%) yang percaya bahwa Roh Kudus selalu membimbing mereka dalam melakukan pekerjaan sehari-hari, $1(0,86 \%)$ mengatakan, "Roh Kudus membimbing bergantung keadaan," l (0,86\%) mengatakan, "Sayalah yang menghalangi Roh Kudus" dan 1 (0,86\%) menjawab, "Tidak pernah memikirkannya." Dari seluruh responden, $75(65,21 \%)$ setuju bahwa gereja meliputi seluruh orang percaya yang ada di dalam gereja termasuk persekutuan para dokter Kristen. Ada 7 responden $(6,08 \%)$ yang tidak menjawab pada kolom aktifitas rohani dan 3 (2,60\%) yang tidak menjawab pada kolom Roh Kudus. 


\section{Apa Arti Penyembuhan}

Penyembuhan mempunyai banyak aspek. Penyembuhan bisa berarti kesembuhan dari penyakit, mental dan rohani. Meskipun dokter Kristen telah terdidik untuk melakukan penyembuhan secara fisik namun sebagai orang beriman, seorang dokter Kristen haruslah melihat kesembuha secara holistik. Dalam penelitian ini ketiganya ditanyakan lepada responden

Jika kesembuhan dilihat sebagai kesembuhan fisik dan rohani, maka ada 107 responden (93,04\%). Hanya ada 3 responden (2,60\%) yang melihat kesembuhan sebagai kesembuhan dari penyakit saja dan 5 responden $(4,34 \%)$ melihatnya hanya dari kesembuhan penyakit dan emosi. Ada 2 responden (1,73\%) yang tidak menjawab pada area pelayanan. Mayoritas responden $(81,73 \%)$ percaya bahwa pelayanan dokter Kristen adalah meliputi pelayanan fisik, emosi dan rohani.

\section{Spiritualitas Pribadi}

Meskipun hasil di atas cukup menggembirakan, namun kelihatannya dalam implementasi sehari-hari pengakuan iman diatas tidak jelas terlihat. Ada ketidak- sesuaian antara kedua hal itu dalam implementasinya. Hanya 37 dari 115 orang responden (32,17\%) yang senantiasa berdoa disertai pembacaan Alkitab yang teratur, 55 responden $(47,82 \%)$ hanya berdoa saja, $3(2,60 \%)$ berdoa jika ada masalah dan $3(2,60 \%)$ bahkan tidak pernah berdoa, (Tabel 16).

Jika kepada responden ditanyakan "Apakah mereka yakin masuk surga jika mereka mati hari ini?" Maka hanya 64 responden $(55,62 \%)$ yang yakin bahwa mereka akan masuk surga jika mereka mati hari ini. 35 responden $(35,35 \%)$ tidak mempunyai keyakinan dengan alasan bermacam-macam dan 16 (13,91\%) yang tidak menjawab.

\section{Bersaksi}

Ada 54 responden (46,95\%) yang sering berdoa dengan pasien mereka yang mempunyai kebutuhan khusus, 46 (40\%) jarang, 13 $(11,30 \%)$ tidak pernah, bahkan ada $2(1,73 \%)$ di antara responden menganggap berdoa bersama pasien dengan kebutuhan khusus bukanlah pekerjaan mereka.

Ada 67 responden $(59,29 \%)$ yang sering menyaksikan kebaikan Kristus kepada orang lain, 39 (33,91\%) jarang, 6 (5,21\%) tidak pernah, 1 $(0,86 \%)$ bahkan mengatakan hal itu bukan pekerjaannya dan 2 responden $(1,73 \%)$ tidak menjawabnya.

Mayoritas (77,77\%) atau 42 dari 54 responden yang sering berdoa dengan pasien yang mempunyai kebutuhan khusus, juga menyaksikan kebaikan Kristus kepada orang lain, (Diagram 2). Sebaliknya, dari 67 
responden yang sering menyaksikan tentang kebaikan Yesus secara verbal, 51 (76,11\%) adalah mereka yang jarang atau bahkan tidak pernah berdoa dengan pasien mereka.

Jika kerajinan melayani dilihat dari keaktifan responden dalam pelayanan lain di luar pelayanan mereka sebagai dokter, maka hanya 35 responden $(30,43)$ yang aktif di pelayanan lain itu, sedangkan 75 responden lainnya $(65,21 \%)$ tidak aktif dan 5 responden $(4,34 \%)$ tidak menjawab.

\section{Makna Sebagai Dokter}

Ada berbagai pendapat responden tentang apa makna mereka sebagai seorang dokter. Berbagai pendapat itu kemudian dibandingkan dengan jawaban mereka terhadap berbagai pertanyaan sehubungan dengan panggilan itu. Jawaban juga dibandingkan dengan pertanyaan lain yang relevan.

Ada 75 responden $(65,21 \%)$ yang saat ini sadar bahwa profesi mereka adalah panggilan Tuhan untuk melayani. Pelayanan dimengerti oleh mayoritas responden sebagai mendatangkan Kerajaan Allah di bumi ini melalui pelayanan mereka.

Ada 94 responden (81,30\%) mengimplementasikannya secara komprehensif sebagai merawat pasien hingga sembuh, belajar serta menambah pengetahuan terus menerus dan mengikuti peraturan dan sumpah dokter. Hanya 22 (19,13\%) yang melihat ketiga aspek di atas secara terpisah. Ada 15 responden (13,04\%) yang tidak menjawab.

\section{Pembahasan Hasil \\ Misi Sebagai Pelayanan Kasih}

Tak dapat dipungkiri, salah satu aspek dari misi Kristen khususnya dalam Injil Lukas adalah pelayanan yang didorong oleh kasih. Kemana pun Tuhan kita pergi, berkali-kali dikatakan dalam Injil, "HatiNya selalu tergerak oleh belas kasihan" melihat orang-orang menderita yang memerlukan pertolongan.

Allan Tippet mengatakan, "The two basic dimensions of missilogical theory and action may be designated as (1) theological and (2) anthropologicaltheological, because the message is a word of God concerning His purpose for and, promise to mankind; anthropological because it has to be communicated within the structure and organization of human societies." 20

Motif kasih yang ditunjukkan oleh Tuhan kita di atas, telah menjadi dorongan bagi banyak orang dalam melakukan pekerjaan pelayanan kemanusiaan di bidang misi. Sebagai bagian dari komunitas xxi.

${ }^{20}$ Alan Tippet, _Missiology (Pasadena, California, William Carey Library, 1987), 
orang Kristen, dokter Kristen juga terhisab untuk melakukan pelayanan kasih seperti di atas dalam pelayanannya setiap hari.

Kasih dokter Kristen memang sukar untuk diukur, namun dapat dirasakan dan dilihat dalam pelayanannya sehari-hari. Seperti sudah disebutkan sebelumnya, dari pengalaman empiris beberapa dokter dan observasi penulis pada beberapa pasien, sensitivitas dan kasih dokter dengan pasiennya dapat diukur dengan ukuran yang bisa dilihat seperti yang sudah dikatakan sebelumnya di atas.

Pelayanan kasih responden dalam penelitian ini diukur dari tarif yang mereka kenakan terhadap pasien, pemberian obat dan perasaan mereka terhadap penderitaan pasien yang mereka hadapi. Lebih dalam lagi, kepada responden juga ditanyakan hal "Apakah mereka juga berdoa untuk pasien mereka"?

Dari seluruh responden, $81,73 \%$ responden yang mempunyai pasien dari golongan menengah-tidak mampu menerapkan tarif yang fleksibel terhadap pasien mereka. Jika diperluas dengan dokter yang mempunyai pasien dari golongan menengah-atas, hasilnya menjadi 93,04\%.

Data-data di atas menunjukkan, dari aspek tarif, dokter Kristen dalam penelitian ini belum terlalu materialistis. Mereka masih mempunyai sensitivitas dalam melihat kemampuan ekonomi pasien mereka di mana mereka memberlakukan tarif pemeriksaan yang fleksibel. Fleksibilitas itu ditunjukkan dengan menyerahkan pembayaran kepada kemampuan pasien sampai memberi gratis bagi mereka yang tidak mampu.

Jika responden dipersempit - sekaligus untuk menguji hasil di atas hal yang sama ditunjukkan oleh dokter bedah. 73,33\% dari responden dokter bedah Kristen ini juga menerapkan tarif yang fleksibel kepada pasien mereka. Hal di atas menarik, sebab jika asumsinya setiap dokter bedah melakukan operasi di rumah sakit, maka biasanya tarif dokter bedah sudah dipatok secara kategorial di setiap rumah sakit.

Hal itu berarti, para dokter bedah Kristen ini, karena masih mempunyai sensitivitas dalam melihat kemampuan pasiennya, maka mereka melakukan intervensi kepada tarif yang sudah dipatok oleh rumah sakit tersebut di atas. Itu dapat mereka lakukan dengan berbagai cara seperti penurunan kategori operasi dari besar menjadi sedang, menganjurkan pasien untuk memilih kelas yang lebih rendah, merawat pasien sebagai pasien one day care dan lain sebagainya.

Tindakan karitatif di atas dapat dibandingkan dengan adanya beberapa dokter yang bekerja sukarela secara paruh waktu untuk 
membuka poliklinik di beberapa gereja untuk membantu warga gereja dan masyarakat sekitar yang kurang mampu. ${ }^{21}$

Sensitivitas terhadap pasien juga ditunjukkan oleh responden di mana 26 responden $(22,60 \%)$, "Selamanya ikut merasakan penderitaan pasien mereka" dan 47 responden (41,26\%), "Sering mendoakan pasien mereka secara pribadi", (Tabel 9).

Hasil di atas juga diperkuat oleh hasil dari penulisan resep di mana 97,39\% responden menuliskan resep mereka berdasarkan rasionalitas, kesanggupan pasien atau memberikan obat generik, (Tabel 8).

Ketiga hasil di atas menunjukkan bahwa mayoritas dokter Kristen di Indonesia dalam penelitian ini belum terlalu materialistis dan masih mempunyai sensitivitas terhadap penderitaan pasien mereka.

Sebagai dokter Kristen, sensitivitas seperti di atas sedikit banyak pastilah didorong oleh kasih Kristus yang bekerja di dalam hati mereka. Keprihatinan terhadap penderitaan pasien, di mana sebagian besar adalah golongan ekonomi menengah-tidak mampu, telah mendorong mereka untuk melakukan perbuatan kasih di atas.

Jika hasil-hasil di atas dikomparasikan dengan perspektif misi dalam Injil Lukas, khususnya terhadap mereka yang miskin dan membutuhkan pertolongan, dapat dikatakan, dokter Kristen dalam penelitian ini telah mempraktikkan kasih dalam pelayanan mereka sehari-hari dengan berpihak kepada orang dari golongan yang tidak mampu. dapat ditambahkan, mereka juga belum menjadi terlalu materialistis.

Lukas banyak menekankan aspek sosial dari pelayanan misi Yesus, khususnya kepada orang-orang miskin dan terpinggirkan. Prefix Yunani pro dari kata kerja proserkomai untuk orang Samaria dalam Lukas 10:34 menunjukkan bahwa orang Samaria itu aktif melakukan sesuatu untuk memenuhi kebutuhan orang yang sedang memerlukan pertolongan.

\section{Misi, Nilai Manusia dan Etika Kedokteran}

Semua pekerjaan filantropis kita kepada manusia, dalam arti pekerjaan yang didorong oleh rasa kasih dan sayang, sangat tergantung dari penilaian kita terhadap nilai manusia itu. Semakin tinggi nilai manusia itu kita beri, semakin besar minat kita untuk melayaninya. Penilaian dokter Kristen akan nilai manusia dalam penelitian ini dibatasi dari pendapat mereka tentang abortus dan eutanasia.

Kedua isu di atas telah menjadi isu nasional dan internasional yang pelik karena menyangkut berbagai aspek seperti yuridis, teologis, etis,

\footnotetext{
${ }^{21}$ Observasi Penulis di Beberapa Gereja di Makassar Yang Membuka Poliklinik Untuk Membantu Orang-Orang Yang Kurang Mampu di dalam dan sekitar lingkungan gereja.
} 
moral, sosial dan hak-hak pribadi untuk menentukan keberadaan dirinya.

Abortus adalah tindakan "penghentian kehamilan sebelum janin berumur kurang dari dua puluh delapan minggu atau berat janin kurang dari 1000 gram."22 Biasanya tindakan ini dilakukan dokter atas indikasi medis seperti eklampsi, penyakit jantung dan penyakit-penyakit lainnya yang dapat membahayakan jiwa sang ibu jika kehamilan tetap dilanjutkan. Tindakan ini secara yuridis, etis dan moral adalah legal.

Dalam penelitian ini, tindakan abortus yang ingin dinilai adalah " abortus provokatus medisinalis." "Abortus provokatus medisinalis" adalah tindakan abortus yang dilakukan bukan karena keperluan medis seperti disebut di atas, melainkan atas indikasi lain yang secara yuridis, etis dan moral adalah ilegal.

Kemajuan teknologi USG tiga dimensi dan pemeriksaan air ketuban yang memanfaatkan kemajuan bioteknologi telah membuat para dokter sekarang dapat menentukan jenis kelamin, cacat bawaan dan penyakit-penyakit lainnya pada janin lebih dini dibanding dengan masa lalu. Hal ini membuka kemungkinan bagi orang tua bayi untuk lebih awal menggugurkan kandungannya jika mereka tidak menghendaki bayinya lahir dengan keadaan-keadaan seperti yang telah disebut di atas. Sementara itu, kemajuan teknologi kedokteran saat ini telah membuat tindakan abortus menjadi lebih mudah dan kurang beresiko dibanding dengan tindakan yang sama pada masa lalu.

Kedua alasan di atas membuat tindakan abortus menjadi lebih mudah dibandingkan dengan masa-masa lalu. Golongan pro-life pasti menentang hal di atas, sebaliknya golongan pro-choice pasti menerimanya

Dari seluruh responden, $80 \%$ responden dalam penelitian ini menjawab, "Abortus mutlak tidak boleh dilaksanakan." 40\% mempertegasnya sebagai "Melanggar sepuluh hukum Allah." Hanya $7,82 \%$ dari responden yang menyetujuinya.

Ironisnya, meskipun $80 \%$ dokter Kristen dalam penelitian ini menjawab abortus mutlak tidak boleh dilaksanakan, namun ada 52,17\% dari responden yang mendengar ataupun mengetahui bahwa ada dokterdokter Kristen yang melakukan tindakan "Abortus provokatus nonmedisinal" seperti disebut di atas.

Apakah ada dari antara 11 responden yang menyetujui "abortus provokatus non medisinalis" yang juga melakukan tindakan abortus, penelitian ini tak dapat menjawabnya.

Dalam wawancara penulis dengan dr. Srimawati Sembiring di Medan pada Desember 201l, dr. Srimawati Sembiring mengatakan, "Saya 743.

${ }^{22}$ Sarwono Prawiroharjo, Ilmu Kebidanan (Jakarta: Yayasan Bina Pustaka, 1981), 
tahu pasti, ada dokter Kristen yang melakukan hal itu hanya untuk uang beberapa jutaan rupiah. Hal itu bukan hanya dilakukan oleh satu orang dokter, tapi dilakukan oleh beberapa dokter Kristen."23

Tindakan lain yang kurang menghargai nilai kemanusiaan adalah "eutanasia". Menurut Kartono Mohammad, dalam kalangan dokter istilah eutanasia berarti, "Membantu seseorang untuk mati lebih cepat demi membebaskannya dari penderitaan akibat penyakitnya." ${ }^{24}$

Di Indonesia, melakukan eutanasia, baik aktif maupun pasif adalah tindakan melanggar hukum. Tindakan itu dapat dikenakan hukuman pidana karena melanggar pasal 334, 338, 340, 345, 359 KUH Pidana.

Perdebatan tentang boleh tidaknya eutanasia tidak akan ada akhirnya termasuk di kalangan dokter sendiri, meskipun sumpah dan kode etik dokter melarang hal itu namun, tetap saja ada dokter yang melakukannya.

Dari beberapa masalah medis-etis-yuridis, eutanasia merupakan masalah yang paling dilematis bagi seorang dokter. Dokter kadangkadang menghadapi kasus di mana seorang pasien menghadapi penyakit yang secara ilmu kedokteran tidak dapat disembuhkan lagi dan pasien meminta kepada dokter untuk mengakhiri hidupnya. Misalnya, pasien dengan kanker stadium terminal di mana pasien sangat menderita dan tidak lagi mempunyai harapan untuk sembuh sehingga minta kepada dokter untuk mengakhiri hidupnya. Dalam hal ini dokter menghadapi keadaan yang dilematis untuk melakukan eutanasia.

Dari seluruh responden, 86,08\% dokter Kristen yang menjadi responden dalam penelitian ini mengatakan, "Eutanasia tidak boleh dilakukan." Hanya 6,95\% yang "setuju." Namun, sama halnya dengan abortus, 25,21\% dari mereka mengetahui, ada dokter Kristen yang melakukan hal itu. Jika ditambah dengan jumlah yang mengatakan "tidak tahu" jumlahnya menjadi 90,43\%.

Bagi kelompok pro-choice dan mereka yang melakukan abortus, bayi-bayi yang kalau lahir tidak mempunyai kualitas hidup yang baik, sakit-sakitan dan tidak produktif di kemudian hari selayaknya digugurkan karena mereka tidak lagi patut hidup. Kehamilan yang tak diinginkan (unwanted child) dapat digugurkan karena hak-hak individu. Sementara itu, mereka yang melakukan eutanasia beranggapan, orangorang dengan penyakit terminal, orang-orang yang tak mempunyai kualitas hidup tak perlu lagi hidup. Mereka hanya menghabiskan

\footnotetext{
${ }^{23}$ Srimawati Sembiring, wawancara oleh penulis, Medan, Desember 2011.

${ }^{24}$ Kartono Mohammad, Teknologi Kedokteran dan Tantangannya Terhadap Bio Etika (Jakarta: PT. Gramedia Pustaka Utama, 1992), 19.
} 
sumber daya yang ada tanpa dapat berarti lagi. Orang-orang seperti itu selayaknya mati.

Untuk melihat bagaimana seharusnya hubungan misi dokter Kristen dengan nilai manusia patut kita simak pandangan Lewis B. Smedes berikut ini. Lewis B. Smedes dalam bukunya Mere Morality mengemukakan empat alasan Alkitab tentang nilai-nilai manusia, dan mengapa tindakan abortus dan eutanasia dilarang.

Pertama, manusia itu suci, itu sebabnya menjadi satu-satunya makhluk ciptaan yang tidak boleh dibunuh. Jika kita melihat manusia kita harus melihatnya sebagai sesuatu yang suci dari pada sesuatu yang berharga.

Kedua, hanya Allah yang mempunyai wewenang untuk mengambil hidup ini. Allah adalah satu-satunya oknum yang dapat menentukan dengan tepat kapan waktu yang tepat bagi seseorang untuk mati.

Ketiga, "Apakah aku penjaga Adikku?" Tanya Kain, ketika dia membunuh adiknya Habel. Secara implisit Allah mengatakan "ya." Kita adalah suatu komunitas dari manusia- manusia yang segambar dengan Allah. Hidup ini hanya mempunyai arti jika kita hidup dalam suatu komunitas. Seorang pun tidak boleh menghancurkannya, melainkan bertanggung jawab menjaga dan memeliharanya.

Keempat, hidup adalah pemberian Allah. Tidak ada satu pun di antara kita yang diminta persetujuannya untuk mau lahir atau tidak. Hidup yang diberikan Allah adalah sesuatu yang baik, namun dapat sewaktu-waktu berubah menjadi pahit.

Ini adalah suatu paradoks kehidupan. Oleh karena itu, menyakini bahwa hidup adalah suatu pemberian Allah merupakan kekuatan untuk menikmati dan mengasihinya. ${ }^{25}$

Dalam Mazmur 139:13-16, Daud melukiskan bagaimana ajaibnya manusia diciptakan Allah,

Sebab Engkaulah yang membentuk buah pinggangku, menenun aku dalam kandungan ibuku. Aku bersyukur kepada-Mu oleh karena kejadianku dahsyat dan ajaib, ajaib apa yang Kau buat, dan jiwaku benar-benar menyadarinya. Tulang-tulangku tidak terlindung bagi$\mathrm{Mu}$, ketika aku dijadikan di tempat tersembunyi, dan aku direkam di bagian-bagian bumi yang paling bawah; mata-Mu melihat selagi aku bakal anak, dan dalam kitab-kitab-Mu semuanya tertulis hari-hari yang akan dibentuk sebelum ada satupun dari padanya.

\footnotetext{
${ }^{25}$ Lewis B. Smedes, Mere Morality (Grand Rapids: William B. Eerdmans Publ. Co, 1986), 104.
} 
Selanjutnya, dalam Mazmur 8:6, Daud melukiskan bagaimana mulianya manusia itu. Manusia itu diciptakan Allah hampir sama seperti Allah.

Kenyataan di atas sungguh mengejutkan dan menjadi tantangan bagi dokter Kristen di Indonesia. Apa pun alasannya, sudah jelas, tindakan eutanasia dan abortus yang dilakukan oleh sebagian dokter Kristen itu bukan saja suatu pembunuhan (pelanggaran hukum VI), melainkan pelanggaran terhadap keseluruhan hukum penciptaan. Selain itu, tindakan abortus dan eutanasia juga merupakan pelanggaran terhadap kedaulatan Allah atas kehidupan ini ( Filipi 1 :21-24).

Dari segi etis, kedua tindakan tercela di atas semakin mengokohkan hasil lain di mana hanya 26,08\% dokter Kristen dalam penelitian ini yang masih memegang teguh etika dan sumpah dokter. Mayoritas dokter-dokter Kristen di Indonesia menurut penelitian ini kurang memegang teguh kode etik dokter Indonesia dan sumpah dokter.

Mengingat ada cukup besar (53,57\%) responden yang menjawab bahwa "ada dokter-dokter Kristen di Indonesia yang melakukan tindakan abortus dan $(25,66 \%)$ yang melakukan eutanasia, maka dapat diinterperetasikan dan dideskripsikan bahwa dokter-dokter Kristen di Indonesia saat ini sudah kurang atau tidak lagi menghargai nilai luhur dari manusia seperti yang ada dalam Injil Lukas dan yang berlaku universal - meskipun kepada dokter-dokter dalam penelitian ini - karena alasan etis, tidak ditanyakan, "Apakah mereka melakukan tindakan aborsi dan eutanasia atau tidak".

Mengingat Injil Lukas adalah Injil yang sangat humanis dan berlaku universal, maka dapat dikatakan dokter Kristen di Indonesia sudah melenceng dari paradigma misi Injil Lukas dalam pelayanannya.

\section{Etika dan Sumpah Dokter}

Etika kedokteran menurut Fred Ameln adalah, "Aturan mengenai kesusilaan dan aturan mengenai kelakuan dan sikap yang secara khusus berlaku untuk dan antar-para dokter sendiri. ${ }^{26}$ Kode Etik Kedokteran Indonesia merupakan kesepakatan dokter Indonesia dalam melaksanakan profesinya. Kode etik itu berisikan: (1) Kewajiban umum, (2) Kewajiban dokter terhadap penderita, (3) Kewajiban dokter terhadap teman sejawat, (4) Kewajiban dokter terhadap diri sendiri.

Sebenarnya, pertimbangan etika pada ilmu kedokteran tidaklah berbeda dengan pertimbangan etika pada ilmu-ilmu lainnya. Kalaupun ada perbedaan, itu adalah dikarenakan adanya keadaan-

\footnotetext{
${ }^{26}$ Fred Ameln, Hukum Kedokteran (Jakarta: Grafikatama Jaya, 1991), 102.
} 
keadaan khusus yang dihadapi seorang dokter dalam menjalankan profesinya yang kadang-kadang menimbulkan dilema etik.

Sebagai contoh, seorang dokter diharuskan memperpanjang kehidupan dan diharuskan meringankan penderitaan pasien. Maka timbullah pertanyaan, apa yang sebaiknya dilakukan? Apa kerugian dan kebaikannya, apakah itu sesuai dengan etika dan sumpah dokter? Beberapa tindakan mungkin baik dari pandangan pasien, tapi belum tentu benar jika ditinjau dari segi etis.

Hal-hal demikian kadang-kadang menimbulkan dilema etis yang tidak selalu gampang dipecahkan dengan kode etik yang tertulis, melainkan kadang-kadang memerlukan perenungan diri yang dalam sebelum dapat memutuskannya.

Selain kode etik, dalam menjalankan profesinya seorang dokter terikat kepada sumpah jabatannya sebagai seorang dokter. Bagi dokter Indonesia, sumpah itu disebut sebagai Sumpah Dokter Indonesia.

Hippokrates sudah menyadari sejak awalnya bahwa perlu ada suatu peraturan-peraturan yang dapat mengendalikan seorang dokter dalam menjalankan profesinya. Ia kemudian menyusun lafal sumpah dokter yang kemudian hari diterima sebagai sumpah dokter sedunia. Sumpah itu kemudian dikenal secara luas sebagai "Sumpah Hippokrates".

Berikut ini adalah isi sumpah itu seperti yang ditulis oleh Gunawan dalam bukunya Memahami Etika Kedokteran yang demikian bunyinya,

Saya akan memperlakukan guru yang telah mengajarkan ilmu ini dengan penuh kasih sayang sebagaimana terhadap orang tua saya sendiri. Jika perlu, saya bagikan hartaku untuk dinikmati bersama, anaknya yang akan saya perlakukan sebagai saudara kandung saya, dan akan saya ajarkan ilmu yang telah saya peroleh dari ayahnya, kalau mereka mau mempelajarinya, tanpa imbalan apapun. Saya juga akan meneruskan ilmu pengetahuan ini kepada anak-anak saya sendiri, dan kepada mereka yang telah mengikatkan diri dengan janji dan sumpah untuk mengabdi kepada ilmu pengobatan dan tidak kepada hal-hal lainnya. Saya akan mengikuti cara pengobatan, yang menurut pikiran dan kemampuan saya akan membawa kebaikan bagi penderita tanpa tujuan yang buruk. Saya tidak akan memberikan obat yang mematikan kepada siapapun meskipun diminta, atau menganjurkan kepada mereka untuk tujuan itu. Atas dasar yang sama, saya tidak akan memberikan obat untuk menggugurkan kandungan. Saya ingin melewati hidup yang saya baktikan kepada ilmu saya ini dengan tetap suci dan bersih. Saya tidak akan melakukan 
pembedahan sendiri, tetapi akan menyerahkannya kepada mereka yang berpengalaman dalam pekerjaan ini. Rumah siapapun yang saya masuki, kedatangan itu saya tujukan untuk kesembuhan yang sakit, dan tanpa niat-niat buruk ataupun membohongi, dan lebih jauh lagi tanpa niat memperkosa wanita atau pria, orang bebas ataupun budak. Apapun yang saya dengar atau lihat tentang kehidupan seseorang yang tidak patut disebarluaskan, tidak akan saya ungkapkan, karena saya harus merahasiakannya. Selama saya tetap mematuhi sumpah saya ini, izinkanlah saya menikmati hidup dalam mempraktikkan ilmu saya ini, dihormati oleh semua orang disepanjang waktu. Tetapi jika saya menghianati sumpah ini balikkanlah nasib saya. ${ }^{27}$

Dalam pelayanannya sehari-hari betapapun tingginya pengetahuan dan teknologi kedokteran yang dimiliki seorang dokter, namun dalam implementasinya, kode etik dan sumpah dokter di atas haruslah menjadi kadar kelakuan (standard of conduct) dari seorang dokter. Tanpa itu, seorang dokter akan gampang terjatuh ke dalam manipulasi dan tindakan-tindakan tercela lainnya

Ketika ditanyakan, "Apakah dokter-dokter Kristen masih memegang kode etik dan sumpah dokter? Hanya 26,08\% responden yang menjawab, "Dokter-dokter Kristen masih memegang teguh etika dan sumpah dokter." Mayoritas responden menjawab, "Dokter Kristen di Indonesia saat ini sudah kurang memegang teguh kode etik dan sumpah dokter." Penilaian itu diperkuat dengan adanya dokter-dokter Kristen yang melakukan tindakan abortus dan eutanasia.

Hal ini patut disayangkan, sebab di tengah-tengah kemajuan teknologi kedokteran dan tergerusnya nilai-nilai moral, maka etika dan sumpah dokter adalah pedoman tertulis yang dapat menjaga kemuliaan profesi dokter.

Jika kita mengacu kepada gejala perubahan sosial yang terjadi sebagai akibat kemajuan teknologi pada zaman ini, maka Alvin Toffler menyebutkan gejala ini sebagai, "Decoding The New Rules." Akibat kemajuan teknologi yang luar biasa saat ini, maka suatu gelombang ketiga saja dapat timbul pada masyarakat, di mana timbul suatu etika baru dalam suatu tatanan masyarakat baru. ${ }^{28}$

Hal yang hampir sama dikatakan oleh J. Sudarminta S.J,

Kehidupan umum masyarakat manusia yang semakin dikuasai oleh budaya ilmu pengetahuan dan teknologi, dengan rasionalitas ilmiahteknologisnya yang bebas nilai, semakin lepas dari kendali dan

\footnotetext{
${ }^{27}$ Gunawan, Memahami Etika Kedokteran (Yogyakarta: Kanisius, 1992), 13-14.

${ }^{28}$ Alvin Toffler. The Third Wave (New York-Toronto: Bantan Books, 1990), 224.
} 
pertimbangan etis. Sebaliknya, dunia nilai-nilai, termasuk di dalamnya nilai-nilai moral, semakin dijadikan urusan privat yang di dasarkan atas pertimbangan parasional dan konvensional. Akibatnya, arah dan tujuan perkembangan peradaban manusia moderen sendiri menjadi tidak jelas. ${ }^{29}$

Hambatan dalam menegakkan etika kedokteran di antara dokter Kristen seperti saat ini sebenarnya telah dijumpai sejak zaman Hellenisme. Sebagaimana halnya sekarang, ada dokter-dokter pada zaman itu yang tidak melaksanakan sumpah Hippokrates dengan sungguh-sungguh. Untuk menunjukkan betapa hambatan dalam menegakkan etika kedokteran sudah dijumpai sejak zaman dulu perhatikanlah kutipan di bawah ini yang diambil dari buku A History of World Societies yang demikian bunyinya,

"Of all men, only a physician with total impunity. Oh no, on the contrary, censure goes to him who dies and he is guilty of excess, and further more he is blamed ... Let me not accuse their (physician) avarice, their gredy deals with those whose fase hangs in the balance, their setting a price on pain, and their demans for down payment in case of death, and their secret doctrines. ${ }^{30}$

Bagi dokter Kristen, dalam hubungannya dengan misi Kristen, sumber pertama etika adalah Alkitab dan teladan Yesus Kristus. Etika dan sumpah dokter yang ada haruslah dilihat sebagai subordinasi dari peraturan-peraturan Allah yang meskipun dibuat oleh manusia, namun harus ditaati dengan sikap baru yakni sebagai bentuk ketaatan kepada Tuhan. Jika dokter Kristen tidak dapat mentaati etika dan sumpah dokter sebagai hukum yang tertulis bagaimana dia dapat mentaati hukum Allah yang tidak tertulis?

Pembicaraan Yesus dengan orang-orang Farisi tentang tradisi agama orang Farisi menunjukkan dengan sangat jelas sentralitas dan otoritas Alkitab dan pendekatan yang diambil-Nya terhadap tradisitradisi itu. ${ }^{31}$ Dokter Kristen harus belajar pada Yesus yang berani menolak tradisi dan etika yang tidak sesuai dengan firman Tuhan.

Meskipun dalam pekerjaannya, dokter kadang-kadang menemukan dilema etis yang tidak selalu gampang dipecahkan dengan kode etik dan sumpah dokter yang tertulis, namun dengan perenungan diri yang dalam serta tuntunan dari Roh Kudus seorang dokter Kristen akan dapat memutuskan hal-hal yang pelik dalam etika.

\footnotetext{
${ }^{29}$ J. Sudarminta S.J. Etika dan Ilmu Pengetahuan, Perlunya Suatu Dialog Dalam NilaiNilai Etis dan Kekuasaan Utopis. ed. Budi Susanto dkk (Yogyakarta: Kanisius,1992) 11.

${ }^{30}$ John P. Mc Kay, Bennet D. Hill, John Buckler, A History of World Societies. Vol I (Boston: Houghton Mifli Co, 1984/, 137.

${ }^{31}$ Dalam Markus 7:1-20 dan Matius 15:1-20, Yesus memperhadapkan tradisitradisi yang dibangun oleh orang-orang Farisi dengan Kitab Suci.
} 


\section{Hubungan Dokter-Pasien Sebagai Hubungan Antar-Manusia}

Dalam hal hubungan dokter-pasien, deklarasi Jenewa dari The World Medical Association telah mengikat seluruh dokter dengan salah satu deklarasinya yang berbunyi, "The health of my patient will be my first consideration".

Pernyataan di atas adalah kalimat kunci untuk memahami hubungan dokter-pasien. Di dalamnya terkandung misi seorang dokter, yakni, untuk mengobati penyakit, mencegah dari kesakitan dan menyelamatkan jiwa pasiennya. Seluruh pengetahuan dokter diabdikan untuk misi ini.

Hubungan dokter-pasien juga tersirat dalam lafal Sumpah Dokter Indonesia yang salah satu bagiannya menyatakan, "Saya akan menghormati setiap hidup insani dari saat pembuahan; saya akan berikhtiar dengan sungguh-sungguh supaya tidak dipengaruhi oleh pertimbangan keagamaan, kebangsaan, kesukuan, perbedaan kelamin, politik kepartaian atau kedudukan sosial dalam menunaikan kewajiban terhadap penderita.

Dari kedua penjelasan di atas jelaslah, bahwa dalam hubungan dokter-pasien, sifat penting yang harus dimiliki oleh seorang dokter dalam pelayanannya terhadap pasien adalah belas kasihan, cinta kasih dan kesetaraan hubungan sebagai penghormatan terhadap hidup insani. Masalahnya, bagaimana hubungan ini dapat dikembangkan dalam masyarakat modern tanpa kehilangan makna sumpah itu sendiri. Bukan hubungan yang muluk-muluk, namun juga bukan suatu hubungan yang tanpa harapan seperti yang diungkapkan orang-orang yang pesimis.

Jika kualitas hubungan dokter-pasien ditinjau dari bentuk hubungan itu sendiri, maka 95 (86,36\%) dokter Kristen dalam penelitian ini menginginkan bentuk hubungan yang setara dengan pasiennya. Hanya $13(11,81 \%)$ dokter Kristen dalam penelitian ini yang masih mempertahankan bentuk hubungan yang paternalistik, (Tabel 15).

Hal di atas adalah suatu perubahan paradigma, mengingat pada masa lalu hubungan dokter-pasien sangat didominasi oleh dokter dan bersifat paternalistik di mana pasien hanya sebagai objek dari kegiatan dokter. Gene Outka mengatakan, "Penghargaan yang setara tampaknya lebih tidak mudah untuk jatuh ke dalam paternalisme; semuanya setara. Di samping itu, penghargaan yang setara mempunyai tempat yang patut untuk penghargaan diri." 32 428), 2008.

${ }^{32}$ Glen H. Stassen. David P. Gushee. Etika Kerajaan, (Surabaya: Momentum, 
Perubahan di atas terjadi tidak terlepas dari dikeluarkannya UU no 8 tahun 1999 tentang perlindungan konsumen. Dalam UU ini hakhak pasien harus diperhatikan karena dijamin oleh UU. Kelalaian dalam memperhatikannya dapat mempunyai implikasi hukum. Bentuk hubungan setara seperti yang dijelaskan di atas akan semakin memberdayakan pasien dan sekaligus menjadi sarana bagi dokter Kristen untuk memproteksi dirinya dari kecenderungan untuk mengeksploitasi pasiennya.

Dengan hubungan yang setara seperti di atas, pasien diberi pilihanpilihan sesuai dengan kemampuannya untuk mendapatkan hasil yang terbaik bagi dirinya. Tak dapat dipungkiri terkadang dokter cenderung memaksakan pemakaian alat-alat diagnostik canggih (over used atau missused) hanya untuk pengembalian nilai investasi alat tersebut atau hal-hal lain sebagainya.

Kesetaraan itu juga tampak di mana 92 responden (80\%) masih memberi obat kepada pasien dengan kriteria, rasionil dan berdasarkan kepada kesanggupan pasien, (Tabel 8).

Apakah perubahan hubungan pasien-dokter di atas didasarkan pada motif yang benar, suci dan kudus, atau akibat paksaan karena adanya UU no 8 tahun 1999 tentang perlindungan konsumen?

Namun, bagaimanapun, hasil di atas menunjukkan bahwa telah terjadi perubahan paradigma yang mendasar dalam hubungan pasiendokter. Ini adalah suatu kesaksian kristiani yang baik di tengah-tengah pekerjaan mereka, baik bagi pasien maupun bagi orang lain.

Dalam pola hubungan yang setara seperti di atas, dokter dan pasien yang ingin memelihara kesehatannya, keduanya mempunyai peran yang aktif dan hubungan yang setara. Pasien dapat menceritakan pengalamannya sendiri berkaitan dengan penyakitnya dan dapat membantu dokter secara aktif dalam menetapkan situasi yang sebenarnya sehingga dokter dapat memberikan nasehat dan pengobatan yang tepat. Di samping itu, hampir seluruh rencana pengobatan terletak di tangan pasien sendiri. Pasien secara sadar dan secara aktif berperan dalam pengobatan dirinya.

Setelah memperhatikan hasil dan pandangan mengenai hubungan dokter-pasien seperti yang dikemukakan di atas, maka didapat suatu kesimpulan bahwa dalam semua jenis hubungan itu, yang terpenting adalah terciptanya suatu kepuasan disertai tanggung jawab timbal balik dan itu hanya dapat dijumpai jika ada kesetaraan hubungan antara dokter dan pasien.

Dalam Injil Lukas kesetaraan adalah suatu keniscayaan. Yesus tidak pernah melakukan eksploitasi, manipulasi dengan orang-orang yang dilayani-Nya, Yesus sangat menghargai orang-orang yang Dia layani sebagai seorang individu. 


\section{Misi dan Kualifikasi Rohani Dokter Kristen}

Kualifikasi rohani atau spiritualitas seorang dokter Kristen sangat berkaitan dengan kemampuannya untuk menjadi saksi bagi Kristus dalam pekerjaannya. Kisah Rasul pasal 2 memberitahu kita, Roh Kuduslah yang menyalakan spiritualitas murid-murid pada waktu itu sehingga mereka mempunyai kualifikasi dan dapat efektif menjadi saksi Kristus.

Tanpa spiritualitas, di tengah semua kesibukan yang ada, dokter Kristen hanya berputar-putar dengan kesibukannya tanpa pernah tahu apa tujuannya untuk hidup dan melayani, dan juga dapat menjadi orang Farisi di zaman modern ini.

Dalam penelitian ini, spiritualitas dokter Kristen diukur dari pengakuan iman mereka seperti pengakuan terhadap Kristus, Roh Kudus, gereja serta apa pendapat mereka tentang kesembuhan. Kepada mereka juga ditanyakan untuk apa mereka menjadi dokter. Pengakuan di atas kemudian dilihat implementasinya dalam kehidupan dan pelayanan mereka sehari-hari.

Seluruh responden mengakui Yesus Kristus sebagai Tuhan, Juruselamat dunia dan Penebus dosa manusia. Ada 109 (94,78\%) yang percaya bahwa Roh Kudus selalu membimbing mereka dalam melakukan pekerjaan sehari-hari. Ada 75 responden $(65,21 \%)$ setuju bahwa gereja adalah meliputi seluruh orang percaya yang ada di dalam gereja termasuk persekutuan dokter-dokter Kristen. Dari aspek pengakuan iman hal di atas sudah cukup baik.

Dari penelitian ini juga terungkap bahwa sebagian besar atau 93,04\% dokter-dokter Kristen dalam penelitian ini masih menganggap kesembuhan pasien mereka adalah kesembuhan holistik yaitu kesembuhan secara fisik dan rohani.

Meskipun saat ini pendapat-pendapat yang mengukur kesembuhan hanya dari segi kualitas fisik terus berkembang, mayoritas dokter-dokter Kristen dalam penelitian ini masih menganggap kesembuhan seperti Alkitab memandangnya.

Nigel M. de S. Cameron mengatakan, "Jika memakai definisi sempit, maka kesembuhan hanyalah dipahami sebagai kesembuhan tubuh. Namun, jika yang dipakai definisi yang lebih luas, maka kesembuhan adalah meliputi kesembuhan mental bahkan rohani." 33

Namun demikian, pengakuan iman responden di atas tidak tampak dalam implementasinya. Hanya 33,91\% dari responden yang membaca Alkitab dan berdoa secara teratur setiap hari. Meskipun ada

\section{4), 2001.}

${ }^{33}$ Nigel M. de S. Cameron. The New Medicine, (Chicago, London: Bioethics Press, 
59,29\% responden yang sering menyaksikan kebaikan Kristus kepada orang lain, namun hanya 46,95\% yang sering berdoa dengan pasien mereka yang mempunyai kebutuhan khusus. 51,30\% dari mereka jarang atau bahkan tidak pernah berdoa dengan pasiennya.

Adakah kesibukan yang menyebabkan sehingga dokter Kristen dalam penelitian ini tidak sempat membaca Alkitab setiap hari secara teratur, masih perlu penelitian lebih lanjut.

Jika spiritualitas dokter Kristen dan hubungan mereka dengan Tuhan dilihat dalam terang Injil Lukas khususnya tentang kualifikasi seorang murid seperti yang ada di dalam Kisah Para Rasul, maka kualifikasi rohani dokter-dokter Kristen yang ada dalam penelitian ini belum sesuai dengan apa yang dimaksud oleh Lukas. Dengan kata lain, mereka belum seperti murid yang digambarkan oleh Lukas dalam tulisan-tulisannya.

Murid-murid sebagaimana yang digambarkan dalam Kisah Para Rasul adalah murid-murid yang rajin berdoa, bertekun dalam pengajaran rasul-rasul. Mereka juga rajin bersaksi kepada orang-orang lain. Muridmurid mengambil bagian secara aktif dalam karya Roh Kudus yang telah dicurahkan pada hari Pentakosta itu.

Dangkalnya spiritualitas juga membuat banyak di antara dokter Kristen ini tidak yakin akan keselamatannya. Jika kepada responden ditanyakan, "Apakah mereka yakin masuk sorga jika mereka hari ini?", maka hanya 64 dari 115 responden $(55,65 \%)$ yang yakin bahwa mereka akan masuk surga jika mereka mati hari ini. Hampir separuh dari mereka masih ragu, menyerahkannya pada keputusan Tuhan, tidak pernah memikirkannya dan ada cukup banyak yang tidak memberi jawaban.

Jelas, ada hubungan yang erat antara kehidupan spiritual yang baik dengan kepastian keselamatan. Hal itu juga ditunjukkan dalam penelitian ini di mana 30 dari 37 responden (81,08\%) yang secara pribadi berdoa dan membaca Alkitab secara teratur yakin bahwa jika mereka mati hari ini mereka akan masuk sorga. Sayang, hal itu hanya terjadi pada 30 dari 115 responden (26,08\%).

Selanjutnya, kepastian keselamatan sebagai akibat dari spiritualitas yang baik akan akan mendorong orang-orang untuk melayani dan bersaksi. Dari 37 responden yang rajin berdoa dan membaca Alkitab, 25 (67,56\%) juga bersaksi kepada pasien-pasien mereka baik dengan berdoa bersama ataupun bersaksi secara verbal. Meskipun mayoritas (77,77\%) dari mereka yang sering berdoa dengan pasiennya juga menyaksikan kebaikan Kristus kepada orang lain, namun sebaliknya, dari 67 responden yang sering menyaksikan tentang kebaikan Yesus secara verbal, $76,11 \%$ adalah jarang atau bahkan tidak pernah berdoa dengan pasien mereka. 
Hasil di atas memperkuat data lain yang menunjukkan bahwa ada lebih banyak dokter Kristen yang mau bersaksi secara verbal (58,26\%), dari yang mau berdoa dengan pasien mereka (46,95\%), dan lebih sedikit lagi yang mau berdoa dan membaca Alkitab secara pribadi dengan teratur (32,17\%). Kelihatannya, lebih mudah bagi sebagian besar dokter Kristen ini untuk bersaksi kepada orang lain secara verbal dari pada berdoa dengan pasien mereka. Lebih dari itu, lebih sulit lagi bagi mereka berdoa dan membaca Alkitab secara pribadi.

Apakah hasil di atas menunjukkan suatu tanda kesibukan, masih perlu penelitian lebih lanjut. Namun demikian, jika melihat dua fakta di bawah ini, kemungkinan besar dokter-dokter Kristen ini telah menjadi begitu sibuk.

Pertama, hanya 35 (31,81\%) dari dokter-dokter Kristen dalam penelitian ini yang terlibat dalam pelayanan lain selain pelayanan sebagai seorang dokter. Kedua, 75\% dari antara mereka saat ini sadar bahwa profesi mereka sebagai dokter adalah panggilan Tuhan untuk melayani. Hal apakah yang menghambat mereka untuk melakukan apa yang mereka sadari? Mengapa terdapat kesenjangan antara kesadaran dan perbuatan?

Penulis yang telah lama melakukan observasi di antara para dokter patut menduga kesibukan adalah penyebabnya. Kesadaran untuk hidup menjadi saksi mengalami hambatan oleh kesibukan mereka. Perlu penelitian lebih lanjut untuk membuktikan hal ini. Adalah fakta, bahwa kesibukan dalam melayani sedikit sekali atau bahkan tidak pernah menghasilkan suatu transformasi. Spiritualitaslah yang menghasilkan transformasi. Contoh-contoh dalam Alkitab menunjukkan, bahwa suatu perjumpaan dan hubungan yang dekat dengan Tuhanlah yang akan menghasilkan spiritualitas.

Akhirnya, melihat mayoritas dari mereka mengaku iman percaya dengan baik, 94,78\% dari mereka yakin bahwa mereka dituntun oleh Roh Kudus ketika mereka bekerja, 65,21\% dari antara mereka saat ini sadar bahwa profesi mereka sebagai dokter adalah panggilan Tuhan untuk melayani, dan melihat mayoritas mereka masih melakukan praktik kasih, namun karena implementasi yang lemah dari aspek misi lainnya, khususnya dalam menghargai nilai-nilai kemanusiaan, berdoa dan bersaksi maka patut juga diduga bahwa telah terjadi legalisme di antara dokter-dokter Kristen dalam penelitian ini. Mereka hanya bersaksi bukan menjadi saksi. Kelihatannya aspek luar lebih mempengaruhi tindakan mereka dari pada aspek dalam batin mereka. 


\section{PENUTUP}

\section{Kesimpulan}

Berdasarkan pembahasan dan uraian dari bab-bab terdahulu, dapat ditarik beberapa kesimpulan sebagai berikut:

Pertama, jika misi dilihat dari aspek kasih, dapat dikatakan dokter Kristen dalam penelitian ini belum terlalu materistis dan telah mempraktikkan kasih itu, khususnya dengan keberpihakan mereka kepada orang-orang miskin. Namun, praktik kasih itu kehilangan artinya mengingat banyaknya dokter Kristen yang melakukan abortus dan eutanasia. Tindakan itu itu dapat diinterpretasikan sebagai kurang atau tidak lagi menghargai nilai luhur dari manusia.

Kedua, pengakuan iman yang baik tidak diimplementasikan dalam kehidupan sehari-hari seperti membaca Alkitab dan berdoa secara teratur. Spiritualitas yang dangkal telah membuat sebagian besar dokter Kristen dalam penelitian ini tidak taat kepada etika dan sumpah dokter, akibatnya banyak dari mereka yang melakukan tindakan tercela seperti abortus dan eutanasia. Akibat lain adalah banyak responden yang ragu akan keselamatannya.

Ketiga, meskipun mayoritas responden sadar bahwa pekerjaan mereka sebagai dokter adalah panggilan Tuhan untuk melayani, namun kesibukan, padatnya jadual telah membuat panggilan itu menjadi kabur.

Keempat, bahaya legalisme mulai tampak melihat banyaknya jumlah mereka yang bersaksi secara verbal, namun tanpa spiritualitas, mempraktikkan kasih tanpa nilai kemanusiaan yang utuh, pengakuan iman dengan bukti yang samar-samar.

Kelima, sekalipun dari aspek kasih, dokter-dokter Kristen dalam penelitian ini kelihatannya sudah melaksanakan misinya, namun secara keseluruhan, setelah dianalisis melalui komparasi, interpretasi dan deskripsi, secara deduktif dapat diambil kesimpulan akhir bahwa mayoritas dokter Kristen dalam penelitian ini dan dokter Kristen di Indonesia mempunyai keinginan untuk melaksanakan misinya, namun masih jauh dari paradigma misi Injil Lukas.

\section{Saran - Saran}

Saran - Saran kami adalah sebagai berikut:

Pertama, dokter-dokter Kristen di Indonesia harus tetap menjalani profesinya dengan tekun sebagai wujud dari panggilan Allah kepada mereka sambil terus bertumbuh secara spiritualitas dan menjadi terang di-tengah-tengah masyarakat.

Kedua, dokter-dokter Kristen di Indonesia harus menjalani hidup yang seimbang antara pelayanan dan spiritualitas. Keseimbangan 
sekaligus adalah cara yang baik untuk menghadapi bahaya legalisme. Ada baiknya dokter-dokter Kristen mengevaluasi kembali jadual-jadual mereka, menguranginya jika terlalu padat sehingga mereka mempunyai waktu yang seimbang antara membaca Alkitab dan berdoa serta menjadi saksi dalam pelayanan mereka.

Ketiga, tetap mengikuti kemajuan iptek kedokteran dengan tujuan agar mereka dapat melayani dengan baik.

Keempat, dokter Kristen dalam diri mereka haruslah mengembangkan prinsip-prinsip "teologi pelayanan medis" dengan mengeksplorasi pelayanan medis seperti yang ada dalam Injil Lukas dan bersama dengan dokter-dokter Kristen lainnya menjadi pelopor bagi terciptanya suatu jalan hidup dan gaya hidup baru dalam pelayanan di bidang medis khususnya di Indonesia.

Kelima, teruslah berusaha untuk memenuhi panggilan pelayanan yang sudah diberikan Kristus dan yang sudah ada dalam setiap sanubari dokter Kristen.

\section{KEPUSTAKAAN}

Alkitab

Alkitab. Jakarta: Lembaga Alkitab Indonesia, 1999.

Kamus

, Kamus Besar Bahasa Indonesia, Jakarta: Balai Pustaka,2001

Strong James, The Exhaustive Concordance of The Bible. Iowa: Word Bible Publishers, n.d.

Sutanto Hasan, Perjanjian Baru Interlinear Yunani-Indonesia dan Konkordansi Perjanjian Baru. Jakarta: LAI, 2003.

, The Analytical Greek-Lexicon. London: Samuel Bagster and Son Limited, 1794.

\section{Buku-Buku}

Ameln Fred. Hukum Kedokteran. Jakarta: Grafikatama Jaya, 1991.

, The Mind of Yesus. New York: Harper \& Row Publisher, 1976. , Matius Pasal 1-10. Jakarta: BPK Gunung Mulia, 1995. Pemahaman Setiap Hari Injil Lukas. Jakarta: BPK Gunung Mulia, 1996.

Blauw, Johannes. "The Missionary Nature of the Church," Crossroads in Mission (New York: Mc Graw-Hill Book Company Inc, 1962. 
Bosch, David J. Transformasi Misi Kristen. Jakarta: BPK Gunung Mulia, 2004.

Cameron Nigel M. de S. The New Medicine, Chicago: Bioethics Press, 174, 2001.

Drane, John. Memahami Perjanjian Baru. Jakarta: BPK Gunung Mulia, 1996.

Duyverman M.E. Pembimbing ke Dalam Perjanjian Baru. Jakarta: BPK Gunung Mulia, 1998.

Dyrness, William.A. Let The Earth Rejoice. A Biblical Theology of Holistic Mission Westchester, Illinois:Crossway Books, 1983.

Ferguson, Sinclair B. Khotbah di Bukit. Surabaya: Momentum, 2005.

Glower, R.H. The Bible Basis of Mission._Chicago: Moody Press,

Gunawan. Memahami Etika Kedokteran. Yogyakarta: Kanisius, 1992.

Guthrie, Donald. Teologi Perjanjian Baru II. Jakarta, BPK Gunung Mulia, 1992.

Hadi, Sutrisno, Metodologi Research, Yogyakarta, Fakultas Psikologi, UGM, 1986.

Heath, Stanley W. Iman, Sains dan Teknologi. Yogyakarta: Yayasan Andi, 1997.

Hendriks, I.W.J. Mendidik Dengan Alkitab dan Nalar. Jakarta: BPK Gunung Mulia, 1995.

Howley G. C. D, Bruce F. F dan Ellison H. L. The New Layman's Bible Comentary. Grand Rapids: Michigan: Zondervan Publishing House, 1979.

Kuiper, de. Missiologia. Jakarta: BPK Gunung Mulia, 1988.

Ladd, G.E. Teologi Perjanjian Baru I. Bandung: Yayasan Kalam Hidup, 2002.

Lena, Hugh F et al. Issues in Society. New York-Singapore: Mac. Graw Hill Inc, 1992.

Lumenta, Benyamin. Pasien. Citra, Peran dan Perilaku. Yogyakarta: Kanisius, 1989.

Mc Kay, John P. D, Hill Bennet, John Buckler. A History of World Societies. Vol I, Boston:Houghton Mifli Co, 1984.

Mohammad, Kartono. Teknologi Kedokteran dan Tantangannya Terhadap Bio Etika.Jakarta: PT. Gramedia Pustaka Utama, 1992.

Peters, George W. A Biblical Theology of Missions. Chicago: Moody Press, 1972.

Prawiroharjo, Sarwono. Ilmu Kebidanan. Jakarta: Yayasan Bina Pustaka, 1981.

Smedes, Lewis B. Mere Morality. Grand Rapids: William B. Eerdmans Publ. Co, 1986. 
Sudarminta, J. S. J. Etika dan Ilmu Pengetahuan, Perlunya Suatu Dialog Dalam Nilai-Nilai Etis dan Kekuasaan Utopis. ed. Budi Susanto dkk (Yogyakarta: Kanisius, 1992.

Stassen, Glen H. Gushee David P. Etika Kerajaan. Surabaya: Momentum, 2008.

Sykes, R.H. Mathew: Presenting Jesus the King. Canada: Everyday Publication Inc, 1984.

Tippet, Allan. Missiology. Pasadena, California: William Carey Library, 1987.

Toffler, Alvin. The Third Wave. New York-Toronto: Bantam Books, 1990.

Sumber Hidup Praktisi Medis, Terj. Tim Yayasan Komunikasi Bina Kasih. Jakarta: Yayasan Bina kasih/OMF, 2002.

Jurnal

Wilmut, I. et all. "Viable Offspring Derived From Fetal and Adult Mamalian Cells, "Nature" 1997.

\section{Internet}

"The Lausanne Committe For The World Evangelization", LCWE South Hamilton (USA), Gospelcom.Net. Diakses pada tanggal 26 Oktober 201l"Missiologi" tersedia di www.Google.com.

\section{Wawancara}

Bambang. Bandung. Wawancara oleh Penulis, Bandung, Jawa Barat, 27 Desember, 2011

Pasulean, Benyamin, konsultasi dengan penulis, Makassar, SulawesiSelatan, 16 Mei, 2012.

Sembiring Srimawati. Wawancara oleh Penulis, Medan, Sumatera Utara, 22 Desember,2011.

Sinaga Ranto Bonar. Wawancara dengan penulis, Medan, Sumatera Utara, 18 Mei, 2012.

Tumbel ,Ronny, Percakapan telepon dengan penulis, 20 Februari, 2012.

Weisman, Ivan. Konsultasi dengan penulis, Makassar, Sulawesi Selatan, 10 Mei, 2012.

Weisman, Ivan. Konsultasi dengan penulis, Makassar, Sulawesi-Selatan, 5 Juni, 2012.

$$
\text { Koran }
$$

“Semangat Pengabdian Dokter Luntur," Kompas, 4 Mei 2012.

E-Mail

Ngelow, Zakaria. E-mail kepada penulis, 6 Maret 2012. 